\title{
Relationship of Family Support to Mother's Compliance Implementing Measles Rubella Immunization in Aceh Tamiang District
}

\author{
Putri Wandari ${ }^{1}$, R. Kintoko Rochadi ${ }^{2}$, Etti Sudaryati ${ }^{3}$ \\ ${ }^{1,2,3}$ Universitas Sumatera Utara, Indonesia \\ Corresponding Author: Putri Wandari
}

\begin{abstract}
Measles and rubella in Indonesia recorded at the Kementerian Kesehatan Republik Indonesia of Indonesia are very large in the last five years. Measles rubella (MR) disease can have a negative impact on children's health in Indonesia. MR immunization is useful for protecting children. The benefit of the MR vaccine is that it can protect children from disability and death caused by pneumonia, diarrhea, brain damage, blindness, deafness, and congenital heart disease. The MR immunization program in Aceh Tamiang District has not achieved success in several sub-districts. This study aims to analyze the relationship between family support and mother's compliance implementing measles rubella immunization in Aceh Tamiang District. This type of research is a quantitative research with observational analytic using a cross-sectional design with a total sample of 98 respondents. The instrument used in this research is a questionnaire. The data obtained in this study were analyzed by univariate and bivariate with chi square test with $\mathrm{p}$ value less than 0.05 . The results showed that $33(33.7 \%)$ were compliant in carrying out MR immunization in children and $65(66.3 \%)$ were not compliant in carrying out MR immunization in children. The results of the bivariate analysis showed that there was a significant relationship between family support $(\mathrm{p}=0.034)$ on mother's compliance implementing measles rubella immunization in Aceh Tamiang District. The role of the Community Health Center (Puskesmas) and the Aceh Tamiang District Health Office is needed in increasing public awareness and participation to comply with MR
\end{abstract}

immunization in children through socialization and counseling to the community.

Keywords: Family Support, Mother's

Compliance, Measles Rubella Immunization

\section{INTRODUCTION}

Indonesia is one of the countries with the fourth most populous population in the world and has been in the demographic bonus from 2012 which is moving towards the opening of a window of opportunity in the period 2020 to 2030 , so that the population structure is prioritized for the productive age group. Indonesia is heading to a stage of increasing economic growth and declining birth rates in the long term. The decline in birth and death rates can affect the age composition of the population. The projection results from 2020 to 2030 can be seen that the balance of the population aged under $0-15$ years is getting smaller and the population of the productive age group (15-64 years) will increase, besides that the elderly are also slowly increasing. This situation can affect the number of dependents (Alisjahbana, 2014).

Changes in population structure by age can occur due to changes in demographic dynamics which are a demographic bonus. The topic of demographic shift exists because the birth rate along with the long term high mortality rate has decreased. The impact that will occur when the birth rate declines in the 
long term is a decrease in the number of people aged less than 0-15 years while the number of people aged 15 to 65 years will increase faster due to the high birth rate in the past. The increasing number of people aged over 64, then increasing rapidly due to the high life expectancy. The number of the productive age population exceeds the number of the non-productive age population, so this is called the demographic bonus situation (Rusli et al., 2015).

The golden period of a child is a time when a child's brain is developing rapidly in life. The golden period develops when the child is in the womb from the age of zero to six years. However, the period of infancy in the womb until the baby is born and is four years old is a very important period. This period is called the golden period or better known as the golden ages (Suyadi, 2010).

Measles and rubella in Indonesia recorded at the Kementerian Kesehatan Republik Indonesia of Indonesia are very large in the last five years. Measles rubella (MR) disease can have a negative impact on children's health in Indonesia. Measles is an infectious disease that is often found in the world and is suspected as a public health problem that must be addressed. Early symptoms of Measles such as fever, conjunctivitis, and the measles virus are found in the splashes of fluid released when sneezing and coughing. Characteristics of reddish patches on the skin appear on the third to seventh day, starting from the face area, then all over, lasting about four to seven days, and sometimes ending with brownish peeling of the skin. Rubella is an infectious disease in children and young adults. This disease will occasionally occur in adults than in children. There are 70 percent of cases of rubella infection in adults which can result in arthritis or arthritis and joint pain.

MR immunization is useful for protecting children. The benefit of the MR vaccine is that it can protect children from disability and death caused by pneumonia, diarrhea, brain damage, blindness, deafness, and congenital heart disease. Based on the Fatwa of the Majelis Ulama Indonesia (MUI) No. 4 of 2016 it is explained that immunization is basically allowed by means of efforts aimed at immunity so as not to be exposed to a certain disease. A person who is not immunized can cause death, serious illness, and permanent disability that can be life-threatening, according to the views of trusted experts, immunization is mandatory. The MR vaccine used has obtained a recommendation from the World Health Organization (WHO) and has a distribution permit from the POM agency. The 95 percent MR vaccine is very efficient in disease prevention (Kementerian Kesehatan, 2018).

MR infection in children can be avoided by immunization. MR immunization is allowed for children aged nine months to 15 years, and is the last immunization provided for infants among other mandatory immunizations. Measles is caused by the Measles virus of the Paramyxovirus group. Measles can cause serious problems, namely blindness, encephalitis, severe diarrhea, ear infections and pneumonia, especially in malnourished children and people whose immune systems are immune. low (Kementerian Kesehatan, 2012).

The immunization program is an effort that can protect someone from getting sick. Immunization is a way to get the body's immunity actively against a disease, so that the affected person will not get sick or only get mild illness. Populations considered vulnerable to infectious diseases will be included in the immunization program, namely infants, school-age children, WUS, and pregnant women. Pregnant women, especially in the first trimester of pregnancy who are exposed to Rubella, may miscarry and babies are born with congenital defects or called CRS. CRS is basically actualized such as congenital heart disease, eye cataracts, reddish spots, microcephaly (small head), and deafness (Kementerian Kesehatan, 2013). 
Putri Wandari et.al. Relationship of family support to mother's compliance implementing measles rubella immunization in Aceh Tamiang District

Infants under 11 months of age are required to receive complete basic immunizations (one dose of hepatitis $\mathrm{B}$, one dose of BCG, three doses of DPT-HB-HiB, four doses of polio drops, and one dose of measles/MR). Basic immunization is very mandatory and MR immunization is a type of immunization that is an important concern, so it is related to the reality that the cause of death in children under five is measles and rubella in pregnant women can have a bad impact, namely congenital defects in babies born. The coverage of MR immunization for infants in Aceh in 2019 was 53 percent, a decrease from the previous year which reached 77 percent and complete basic immunization coverage was 51 percent (Dinas Kesehatan Aceh, 2018).

The government is moving to reduce morbidity, mortality, and disability due to diseases that can be prevented by immunization (PD3I), and can be determined through overall immunization coverage in all urban villages. Immunization is an effort to form immunity to form antibodies that aim to fight disease. The ingredients contained in the vaccine aim to increase the formation of antibody substances that are injected into the body such as BCG, DPT, hepatitis B, MR, and polio vaccines given by mouth (Momomuat et al., 2014).

The implementation of measles/MR immunization for children is not only to prevent certain diseases, but can have a wide impact because MR immunization can break the transmission line for other children. If immunizations are not carried out on time, the immune system received will not be maximized, so to understand the benefits of immunization for children, parents/mothers are very important to have knowledge about immunization (Ranuh, 2011).

The MR immunization program in Aceh Tamiang District has not achieved success in several sub-districts. Based on the results of a preliminary survey conducted at the Community Health Center (Puskesmas) that the MR vaccine was received in Aceh in August 2018 and a survey was also conducted on mothers who have toddlers in Aceh Tamiang District, 35 mothers $(100 \%)$ were interviewed, 16 $(45,71 \%)$ were interviewed. Mothers who are willing to give their children MR immunization, as many as 21 (60\%) mothers receive family support but of the 21 mothers who receive family support there are five mothers who are not willing to give their children immunization, as many as 15 (42.85\%) mothers consider MR immunization harm, as many as 18 $(51.42 \%)$ mothers are afraid because of the issue of illness and death after being given immunizations, and from the results of interviews conducted at the puskesmas there are 19 mothers who are not willing to have their children immunized, then the percentage obtained obtained (54.28\%).

This study aims to analyze the relationship between family support and mother's compliance implementing measles rubella immunization in Aceh Tamiang District.

\section{RESEARCH METHODS}

This type of research is a quantitative research with observational analytic. Observational analysis is a survey or research that tries to explore how and why health phenomena occur (Notoatmodjo, 2012).

The population in this study were all children under five who were in three sub-districts of Aceh Tamiang Regency, which had been in clusters of 11 subdistricts. The total population is 4,112 toddlers and the population in this study are mothers of toddlers who are in three subdistricts of Aceh Tamiang Regency. Observational analytic using a crosssectional design with a total sample of 98 respondents.

The instrument used in this research is a questionnaire.

The data obtained in this study were analyzed by univariate and bivariate with chi square test with $\mathrm{p}$ value less than 0.05 . 
Putri Wandari et.al. Relationship of family support to mother's compliance implementing measles rubella immunization in Aceh Tamiang District

\section{RESULT}

\section{Overview of Research Locations}

$\begin{array}{ccc}\text { Aceh } & \text { Tamiang Regency is } \\ \text { astronomically } & \text { located } & \text { between }\end{array}$ 0353'18.81"-04³2'56.76" North Latitude and $97^{\circ} 43^{\prime} 41.51^{\prime \prime}-98^{\circ} 14^{\prime} 45.41^{\prime \prime} \quad$ East Longitude. Based on its geographical location, Aceh Tamiang Regency is at the eastern end of Aceh Province, bordering North Sumatra Province and based on its geographical position, Aceh Tamiang Regency has boundaries, namely in the north it borders East Aceh Regency, Langsa City and the Malacca Strait. In the east it is bordered by Langkat Regency, North Sumatra Province and the Malacca Strait. To the south, it is bordered by Langkat Regency, North Sumatra Province and Gayo Lues Regency. Then in the west it is bordered by East Aceh Regency and Gayo Lues Regency.

Administratively, Aceh Tamiang Regency consists of 12 sub-districts, 213 villages with a population of around 294,356 Aceh Tamiang Regency. The economic structure of the Aceh Tamiang community consists of the categories of agriculture, forestry, fisheries, mining, wholesale and retail trade, construction, processing industry, as well as transportation and warehousing. Aceh Tamiang's economic growth can be said to tend to be good.

This research was conducted in Aceh Tamiang District, because the success of measles rubella (MR) immunization has not been achieved in Aceh Tamiang District. The sampling sites in this study were in three sub-districts of Aceh Tamiang
Regency, including Kota Kualasimpang District, Rantau District, and Banda Mulia District. Kota Kualasimpang sub-district has one health center, Rantau sub-district has one hospital and two health centers, and Banda Mulia sub-district has one health center. The sample in this study was 98 samples and the samples were toddlers who were represented by mothers of toddlers from three sub-districts in Aceh Tamiang Regency.

\section{Univariate Analysis}

Univariate analysis was carried out to see the frequency distribution data of each variable. In this study the variable of family support.

Table 1: Data on the Distribution of Mother's Compliance Measles Rubella (MR) Immunization in Aceh Tamiang District in 2021

\begin{tabular}{|l|c|c|}
\hline \multirow{2}{*}{} & \multicolumn{2}{|c|}{$\begin{array}{c}\text { Mother's Compliance Implementing } \\
\text { Measles Rubella Immunization }\end{array}$} \\
\cline { 2 - 3 } & $\mathbf{N}$ & \% \\
\hline Compliant & 33 & 33.7 \\
\hline Not Compliant & 65 & 66.3 \\
\hline
\end{tabular}

Based on Table 1, the results showed that $33(33.7 \%)$ were compliant in carrying out MR immunization in children and 65 $(66.3 \%)$ were not compliant in carrying out MR immunization in children.

\section{Bivariate Analysis}

Bivariate analysis was carried out to analyze whether or not there was a relationship between the independent variable, namely family support to the dependent variable, namely mother's compliance implementing measles rubella immunization in Aceh Tamiang District.

Table 2: Relationship Frequency of Family Support in Aceh Tamiang District 2021

\begin{tabular}{|l|c|c|c|c|c|c|c|}
\hline \multirow{3}{*}{ Variable } & \multicolumn{2}{|c|}{ Mother's Compliance Implementing Measles Rubella Immunization } & \multirow{2}{*}{ P-Value } \\
\cline { 2 - 7 } & \multicolumn{2}{|c|}{ Compliant } & \multicolumn{2}{c|}{ Not Compliant } & \multicolumn{2}{c|}{ Total } & \\
\cline { 2 - 6 } & $\mathbf{n}$ & $\boldsymbol{\%}$ & $\mathbf{n}$ & $\mathbf{\%}$ & $\mathbf{n}$ & $\mathbf{\%}$ & \\
\hline Family Support & & & & & & & \\
\hline Good & 18 & 46.2 & 21 & 53.8 & 33 & 100 & 0.034 \\
\hline Bad & 15 & 25.4 & 44 & 74.6 & 65 & 100 & \\
\hline
\end{tabular}

The relationship between family support and mother's compliance implementing measles rubella immunization for compliant shows that of 33 mothers in the good category, 18 mothers (46.2\%) were compliant and 21 mothers $(53.8 \%)$. Then from 65 mothers in the bad category, mothers who did not comply in carrying out MR immunization for not compliant were 44 mothers $(74.6 \%)$. 
Putri Wandari et.al. Relationship of family support to mother's compliance implementing measles rubella immunization in Aceh Tamiang District

Based on results of the bivariate analysis showed that there was a significant relationship between family support $(\mathrm{p}=0.034)$ on mother's compliance implementing measles rubella immunization in Aceh Tamiang District.

\section{CONCLUSION AND SUGGESTION}

The results showed that $33(33.7 \%)$ were compliant in carrying out MR immunization in children and $65(66.3 \%)$ were not compliant in carrying out MR immunization in children. The results of the bivariate analysis showed that there was a significant relationship between family support $(\mathrm{p}=0.034)$ on mother's compliance implementing measles rubella immunization in Aceh Tamiang District.

The role of the Community Health Center (Puskesmas) and the Aceh Tamiang District Health Office is needed in increasing public awareness and participation to comply with MR immunization in children through socialization and counseling to the community.

Acknowledgement: None

Conflict of Interest: None

Source of Funding: None

\section{REFERENCES}

1. Alisjahbana, Armida S. (2014). Rancangan Teknokratik RPJMN 2015-2019. Jakarta: Bappenas.
2. Dinas Kesehatan Aceh. (2018). Profil Kesehatan Aceh. Banda Aceh.

3. Kementerian Kesehatan. (2012). Profil Kesehatan Indonesia 2015. Jakarta: Kementerian Kesehatan Republik Indonesia.

4. Kementerian Kesehatan. (2013). Penyelenggaraan Imunisasi. Jakarta: Kementerian Kesehatan Republik Indonesia.

5. Kementerian Kesehatan. (2018). Informasi Situasi Campak dan Rubella di Indonesia. Jakarta: Kementerian Kesehatan Republik Indonesia.

6. Momomuat, Silvia, Amatus Yudi Ismanto \& Rina Kundre. (2014). Hubungan Tingkat Pengetahuan Ibu Tentang Pentingnya Imunisasi Campak dengan Kepatuhan Melaksanakan Imunisasi di Puskesmas Kawangkoan. Jurnal Keperawatan, 2(2).

7. Notoatmodjo S. (2012). Promosi Kesehatan dan Perilaku Kesehatan. Jakarta: PT Rineka Cipta.

8. Ranuh, I.G.N. (2011). Pedoman Imunisasi di Indonesia. Jakarta: Badan Penerbit Ikatan Dokter Anak Indonesia.

9. Rusli, S., Toersilaningsih, R., Meirida, D., Kurniawan, U. K., \& Setiawan, K. D. (2015). Potensi dan Implikasi Bonus Demografi di Provinsi Banten Tahun 20152035. Jakarta: Direktorat Analisis Dampak Kependudukan BKKBN.

10. Suyadi. (2010). Psikologi Belajar Anak. Yogyakarta: Pedagogia.

How to cite this article: Wandari P, R. Kintoko Rochadi, Sudaryati E. Relationship of family support to mother's compliance implementing measles rubella immunization in Aceh Tamiang District. International Journal of Science \& Healthcare Research. 2021; 6(3): 273-277. DOI: https://doi.org/10.52403/ijshr.20210747 